\title{
Developing EFL Reading Comprehension Through Using Collaborative Strategic Reading Approach
}

\author{
Dina Zaki Amasha Abd El-Razik
}

\begin{abstract}
This study aimed at investigating the effectiveness of Collaborative Strategic Reading (CSR) in developing reading comprehension skills of EFL secondary stage students. Two intact classes of second year secondary stage students from Belqas Al-Azhar Secondary Institute for Girls participated in this study. One class $(\mathrm{N}=30)$ was assigned as the experimental group and received CSR instruction. The other class $(\mathrm{N}=30)$ was assigned as the control group and received regular instruction of reading comprehension. The treatment lasted for 12 weeks. To collect data, a pre-post reading comprehension skills test was used to assess the EFL students' reading comprehension skills before and after the treatment. T-Tests and Eta-square ( $\eta 2$ ) were used to analyze the data statistically. Results showed that there is a statistically significant difference at the 0.01 level between the mean score of the experimental group students and that of the control group on the postadministration of the reading comprehension test in favor of experimental group students. Based on the findings of this study, it could be concluded that CSR had a positive effect on developing secondary stage students' reading comprehension skills and was more effective in developing critical comprehension skills than inferential or literal comprehension skills.
\end{abstract}

Keywords: Collaborative Strategic Reading (CSR), reading comprehension skills, EFL

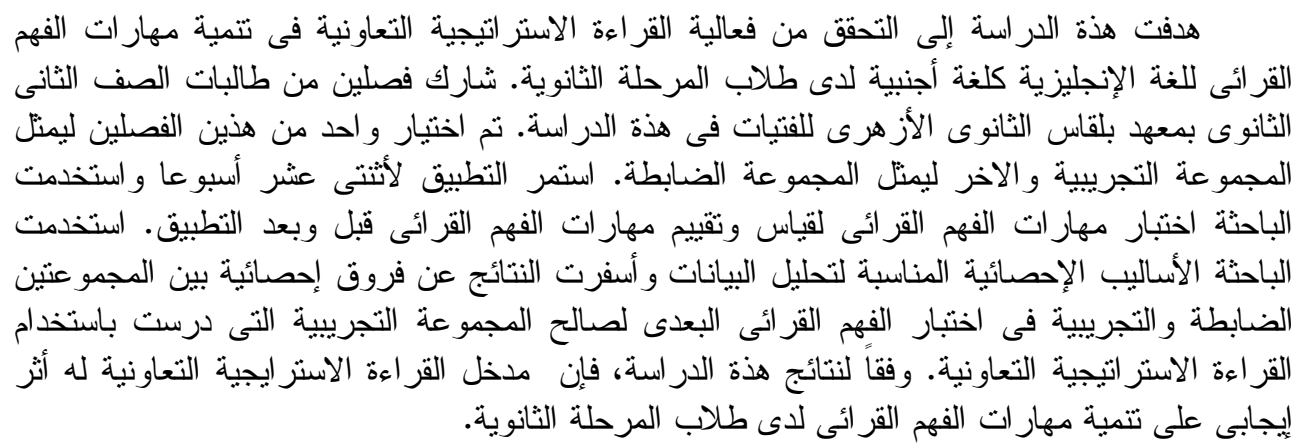




\section{Introduction}

Reading is an important language skill. It is a bridge to world knowledge. Learners obtain knowledge of any field, absorb information of any kind, and explore this changing world through the processing of reading. Reading also helps learners to enhance their overall language proficiency, activate their minds, develop their creativity and imagination and widen their vision (Keyser, 2015). The centrality of reading in our lives has been the reason for the surge of interest in the study of reading.

\section{Reading Process}

Reading is a twofold process. First, it is a process of decoding a printed material and second, it is an active process of constructing meaning (comprehension). According to this perspective, the reading process includes two integrated dimensions.

- The first dimension involves processing the words visually; identifying their phonological, orthographic, and semantic representations; and then connecting the words of a sentence using rules of syntax to understand the underlying meaning of that sentence (Perfetti \& Stafura, 2014).
- The second dimension involves integrating the meaning across sentences, making use of relevant background knowledge, generating inferences, identifying the text structure, and considering the authors' goals and motives (Graesser, 2015).

Merging these two dimensions results in "a mental representation that reflects the overall meaning of the text" (Kendeou, McMaster, \& Christ, 2016).

Thus, comprehension is the goal and purpose of reading. Without comprehension, reading is a meaningless activity of word decoding. It is no exaggeration to say that developing reading comprehension affects greatly on students' success in school and life as reading comprehension has been described as "the most critical skill students need to be successful in school" (Watson et al., 2012, p. 80)

Therefore, reading comprehension instruction should aim to help students become competent and proficient readers by providing various effective instructional approaches such as comprehension strategy instruction and cooperative learning. 
Table 7. Comparing the performance of the experimental and control groups on the post-administration of the reading comprehension test

\begin{tabular}{|l|l|l|l|l|l|l|}
\hline \multirow{2}{*}{ Reading comprehension skills } & \multicolumn{2}{|c|}{$\begin{array}{c}\text { Experimental } \\
\text { Group } \\
\text { (N=30) }\end{array}$} & \multicolumn{2}{|c|}{$\begin{array}{c}\text { Control } \\
\text { Group (N=30) }\end{array}$} & $\begin{array}{c}\text { t- } \\
\text { value }\end{array}$ & \multirow{2}{*}{ Sig. } \\
\cline { 2 - 6 } & mean & S. D. & mean & S. D. & & \\
\hline Identifying the main idea & 3.20 & 0.99 & 1.86 & 1.27 & 4.50 & 0.01 \\
\hline Reading for details & 3.00 & 1.01 & 1.90 & 1.22 & 3.66 & 0.01 \\
\hline Reading for specific information & 3.13 & 1.36 & 1.86 & 1.27 & 4.05 & 0.01 \\
\hline Identifying reference words & 3.33 & 1.09 & 1.80 & 1.42 & 4.67 & 0.01 \\
\hline Literal comprehension skills & 12.66 & 2.94 & 7.46 & 3.96 & 5.77 & 0.01 \\
\hline $\begin{array}{l}\text { Inferring cause and effect } \\
\text { relationships }\end{array}$ & 2.93 & 1.14 & 1.66 & 1.39 & 3.84 & 0.01 \\
\hline $\begin{array}{l}\text { Making inferences and Drawing } \\
\text { conclusions }\end{array}$ & 2.60 & 1.40 & 1.46 & 1.38 & 3.14 & 0.01 \\
\hline Inferring sequences of events & 2.73 & 1.22 & 1.66 & 1.39 & 3.13 & 0.01 \\
\hline $\begin{array}{l}\text { Inferring the meaning of unknown } \\
\text { words }\end{array}$ & 3.00 & 1.14 & 1.93 & 1.33 & 3.31 & 0.01 \\
\hline Inferential comprehension skills & 11.26 & 3.03 & 6.73 & 4.15 & 4.82 & 0.01 \\
\hline Figuring out the author's purpose & 2.66 & 1.32 & 1.60 & 1.22 & 3.24 & 0.01 \\
\hline Distinguishing fact from opinion & 2.53 & 1.38 & 1.46 & 1.27 & 3.10 & 0.01 \\
\hline Expressing personal opinions & 3.16 & 0.74 & 2.06 & 0.94 & 5.00 & 0.01 \\
\hline Summarizing & 4.33 & 1.21 & 2.56 & 1.10 & 5.89 & 0.01 \\
\hline Critical comprehension skills & 12.70 & 3.82 & 7.70 & 3.87 & 5.02 & 0.01 \\
\hline Total & 36.63 & 9.48 & 21.90 & 11.55 & 5.39 & 0.01 \\
\hline
\end{tabular}

Results in table 7 illustrate that the calculated $t$-values are significant at the 0.01 level with regard to the reading comprehension sub-skills, levels of reading comprehension, and the total score of the test. All the calculated t-values in table 7 are greater than the critical t-value (2.46) at the 0.01 level of significance. Table 7 indicates that the $\mathrm{t}$ - value for the literal comprehension skills is (5.77), the t-value for the inferential comprehension skills is (4.82), the tvalue for the critical comprehension skills is (5.02) and the t- value for the total test score is (5.39). According to that, it can be concluded that there is a statistically significant difference at the 0.01 level between the mean score of the experimental group students and that of the control group on the postadministration of the reading comprehension test in favor of experimental group students. These results indicate the improvement of experimental group students' reading comprehension skills after the treatment in comparison with the control group students and provide evidence for the effectiveness of CSR 
in developing the experimental group students' reading comprehension skills.

\section{Testing the second hypothesis}

There is a statistically significant difference at the 0.01 level between the mean score of the experimental group students on the pre- and post-administration of the reading comprehension test in favor of the post-administration.

A dependent samples t-test was used to test the second hypothesis. Results are shown in Table 8.

Table 8. Comparing the performance of the experimental group on the pre- and post-administration of the reading comprehension test.

\begin{tabular}{|c|c|c|c|c|c|c|}
\hline \multirow{2}{*}{ Reading comprehension skills } & \multicolumn{2}{|c|}{$\begin{array}{c}\text { Pre-test } \\
(\mathrm{N}=30)\end{array}$} & \multicolumn{2}{|c|}{$\begin{array}{c}\text { Post-test } \\
(\mathbf{N}=\mathbf{3 0})\end{array}$} & \multirow{2}{*}{$\begin{array}{c}\text { t- } \\
\text { value }\end{array}$} & \multirow[t]{2}{*}{ Sig. } \\
\hline & mean & S. D. & mean & S. D. & & \\
\hline Identifying th & 1.73 & 1.25 & 3.20 & 0.99 & 8.93 & 0.01 \\
\hline Reading for details & 1.80 & & 00 & - & 59 & 0.01 \\
\hline & 86 & & & & 23 & 0.01 \\
\hline Identifying reference words & 1.80 & 1.42 & 3.33 & 1.09 & 6.70 & 0.01 \\
\hline Literal comprehension skills & 7.20 & 3.91 & 12.66 & ? & 13.85 & 0.01 \\
\hline lationships & 1.60 & & & & 61 & 0.01 \\
\hline $\begin{array}{l}\text { Making inferences and Drawing } \\
\text { conclusions }\end{array}$ & 1.46 & 1.27 & 2.60 & 1.40 & 15 & 0.01 \\
\hline Inferring sequences of events & 1.5 & 1.25 & & 1. & 83 & 0.01 \\
\hline $\begin{array}{l}\text { Inferring the meaning of unknown } \\
\text { words }\end{array}$ & 1.73 & & & & 7 & 0.01 \\
\hline ion skills & 6.33 & 4.00 & 11.26 & 3.03 & 12.57 & 0.01 \\
\hline 's purpose & 1.40 & & 266 & 1. & 7.07 & 0.01 \\
\hline Distinguishing fact from opinion & 1.3 & 1.32 & 2.53 & 1. & 3 & 0.01 \\
\hline ing nerconnl & 1.90 & 0.92 & 3 & 0.74 & 39 & 0.01 \\
\hline Summ & 2.46 & 1.19 & 4.33 & 1.21 & 23.54 & 0.01 \\
\hline & 7.10 & & 12.70 & 3.8 & 16.75 & 0.01 \\
\hline Total & 20.63 & 11.80 & 36.63 & 9.48 & \begin{tabular}{|l|}
15.57 \\
\end{tabular} & 0.01 \\
\hline \multicolumn{7}{|c|}{$\begin{array}{ll}\text { Results in Table } 8 \text { indicate that } & \text { the t-value for the inferential } \\
\text { the calculated t-values are significant } & \text { comprehension skills is }(12.57) \text {, the t- } \\
\text { at the } 0.01 \text { level with regard to the } & \text { value for the critical comprehension } \\
\text { reading comprehension sub-skills, } & \text { skills is }(16.75) \text { and the t-value for the } \\
\text { levels of reading comprehension, and } & \text { total test score is }(15.57) \text {. These } \\
\text { the total score of the test. Table } 8 & \text { values show that the experimental } \\
\text { indicates that the t- value for the } & \text { group students r reading } \\
\text { literal comprehension skills is (13.85), } & \text { comprehension skills increased }\end{array}$} \\
\hline
\end{tabular}


significantly after using CSR. According to these values, it can be concluded that there is a statistically significant difference at the 0.01 level between the mean score of the experimental group students on the pre- and post-administration of the reading comprehension test in favor of the post-administration. These results show the positive impact of the CSR treatment on developing second year secondary stage students' reading comprehension skills and answer the study question: To what extent is Collaborative Strategic Reading effective in developing reading comprehension skills of second year Al-Azhar secondary stage students?

\section{Discussion of Results}

Results reported a statistically significant difference between the control group and the experimental group in favor of the experimental group. They also revealed a great improvement in the experimental group students' reading comprehension skills on the post administration of the reading comprehension test. All these results fostered the positive effect of collaborative strategic reading approach in developing reading comprehension skills of secondary stage students.

Combining two important teaching practices: cooperative learning and reading comprehension strategies, CSR yielded positive outcomes. CSR provided opportunities for students to interact effectively with peers and enhance comprehension through using effective reading comprehension strategies.

In addition, comprehension strategy instruction provided students with actionable steps that they followed before, during, and after reading to overcome barriers to comprehension and enhance extracting meaning from the text. Moreover, the group dynamics generated in cooperative group work, ensured students' strategic reading and active engagement and produced the motivation necessary for comprehension to take place. Each student had a role to perform within the group and each of these roles helped the group to achieve their reading goals successfully. During group discussions, students assisted one another in understanding the meaning of challenging words, getting the main idea, asking and answering questions, and establishing relationships what they were reading and their previous knowledge. Besides, English language sessions during which the students worked cooperatively using CSR were favorable for the students. All these factors contributed to developing students' reading comprehension skills. 


\section{Conclusions}

According to the results of this study, it was concluded that:

1.Collaborative Strategic Reading approach had a positive effect on developing secondary stage students' reading comprehension skills.

2.Employing reading comprehension strategies in an effective manner enhanced reading comprehension of secondary stage students.

3.Using cooperative learning techniques helped secondary stage students improve their reading comprehension skills.

\section{Recommendations}

In the light of the results and conclusions of this study, the following recommendations are suggested:

1. EFL teachers should integrate strategy instruction as a central component of reading comprehension instruction and train students to use a number of reading comprehension strategies and teach them how, why, and when to use these strategies independently to read different texts efficiently.

2.EFL teachers should replace the traditional whole-class, teacherled approach that involves introducing vocabulary, reading the text and answering the questions at the end with different cooperative learning techniques to ensure strategic reading and active engagement with the text and to generate the motivation necessary for comprehension to take place.

3.EFL teachers should encourage students to read different types of texts: books, magazines, journals, novels and other reading materials that engage them in the reading process.

4.EFL teachers should engage students in high-level academic discussions and support students' language acquisition through academic discourse with peers.

\section{References}

Abidin, M. J. Z. (2012). Collaborative Strategic Reading (CSR) within cognitive and metacognitive strategies perspectives.

European Journal of Business and Management, 4(1), 61-69. Retrieved from http://www.iiste.org/Journals/in dex.php/EJBM/article/downloa d/1027/947

Agustini, N. M. S., Marhaeni, A. I. N., \& Suarnajaya, W. (2013). The effect of cooperative learning techniques and students' attitude on the reading comprehension of the eleventh grade students of Sman I Kediri. E-journal Penelitian, 1. Retrieved from https://media.neliti.com/media/p 
ublications/118852-EN-the-

effect-of-cooperative-learningtechn.pdf

Alexander, P. A., \& The Disciplined Reading and Learning Research Laboratory (2012). Reading into the Future: Competence for the 21 st Century. Educational Psychologist, 47(4), 259-280. Retrieved

fromhttps://www.researchgate.n et/publication/272479303_Read ing Into

the Future Competence for th e 21st_Century

Anonym. (2010). Teaching Metacognitive Reading Strategies to Second Language Learners in a Classroom Setting, Seminar Paper. GRIN Verlag.

Boardman, A. G., Vaughn, S., Buckley, P., Reutebuch, C., Roberts, G. \& Klingner, J. (2016). Collaborative strategic reading for students with learning disabilities in upper elementary classrooms. Exceptional Children, $1-19$. Retrieved from http://ecx.sagepub.com/content/ early/2016/03/17/00144029156 25067. full.pdf

Bolukabas, F., Keskin, F., \& Polat, M. (2011). The effectiveness of cooperative learning on reading comprehension skills in Turkish as foreign language. The Turkish Online Journal of Educational Technology, 10 (4), 330-335. Retrieved from https://files.eric.ed.gov/fulltext/ EJ946641.pdf

Bryant, D. P., Vaughn, S., LinanThompson, S., Ugel, N., Hamff, A., \& Hougen, M. (2000). Reading outcomes for students with and without reading disabilities in general education middle-school content area classes. Learning Disability Quarterly, 23(3), 24-38. Retrieved from https://journals.sagepub.com/do $\mathrm{i} / \mathrm{pdf} / 10.2307 / 1511347$

Gani, S. A., Yusuf, Y. Q., \& Susiani, R. (2016). Progressive outcomes of collaborative strategic reading to EFL learners. Kasetsart Journal of Social Sciences, 37(3), 144-149. Retrieved from http://www.sciencedirect.com/s cience/article/pii/S24523151163 $\underline{00261}$

Grabe, W. (2009). Reading in a second language: Moving from theory to practice. Cambridge, UK: Cambridge University Press.

Graesser, A. C. (2007). An introduction to strategic reading comprehension. In D. McNamara (Ed.), Reading comprehension strategies: 
Theories, interventions, and technologies (pp. 3-26).

Mahwah, NJ: Lawrence Erlbaum.

Graesser, A. C. (2015). Deeper learning with advances in discourse science and technology. Policy Insights from the Behavioral and Brain Sciences, 2, 42-50. Retrieved from

https://journals.sagepub.com/do i/10.1177/2372732215600888

Guthrie, J. T., Hoa, A. L. W., Wigfield, A., Tonks, S. M., Humenick, N. M., \& Littles, E. (2007). Reading motivation and reading comprehension growth in the later elementary years. Contemporary Educational Psychology, 32(3), 282-313. Retrieved from https://www.researchgate.net/pu blication/222672247 Reading motivation and reading comprehension gr owth in the later elementary years

Hansen, E. J. (2016). Reading Comprehension. Retrieved from https://brage.bibsys.no/xmlui/bit stream/id/433102/16-00400-

Kendeou, P., Mcmaster, K. L., \& Christ, T. J. (2016). Reading Comprehension: Core Components and Processes. Policy Insights from the Behavioral and Brain Sciences,
3(1), 62-69. Retrieved from https://journals.sagepub.com/do i/full/10.1177/23727322156247 $\underline{07}$

Keyser, A. (2015, July 22). Why is Reading Important? [Blog Post]. Retrieved from https://www.worksheetcloud.co $\mathrm{m} / \mathrm{blog} /$ why-is-readingimportant/

Khonamri, F. \& Karimabadi, M. (2015). Collaborative strategic reading and critical reading ability of intermediate Iranian learners. Theory and Practice in Language Studies, 5(7), 13751382.

Retrieved fromhttp://www.academypublic ation.com/ojs/index.php/tpls/arti cle/viewFile/tpls050713751382/ $\underline{300}$

Klingner, J. K. \& Vaughn, S. (1998). Using collaborative strategic reading. Teaching Exceptional Children, 30(6), 32-37. Retrieved fromhttps://journals.sagepub.co $\underline{\mathrm{m} / \mathrm{doi} / \mathrm{pdf} / 10.1177 / 0040059998}$ 03000607

Klingner, J. K. \& Vaughn, S. (1999). Promoting reading comprehension, content learning, and English acquisition through collaborative strategic reading (CSR). The Reading Teacher, 52(7), 738-747. Retrieved from https://www.researchgate.net/pu 
blication $/ 286975378$ Promoting

reading

comprehension_content learnin

g_and English_acquisition tho ugh_Collaborative_Strategic_R eading CSR

Klingner, J. K., Vaughn, S., Dimino, J., Schumm, J. S., \& Bryant, D. (2001). Collaborative strategic reading: Strategies for improving comprehension. Longmont, CO: Sopris West.

Klingner, J. K., Vaughn, S., \& Broadman, A. (2007). Teaching reading comprehension to students with learning difficulties. What works for special-needs learners (K. R. Harris and S. Graham, Eds.). New York: The Guildford Press. Retrieved from http://www.academia.edu/5395 148/Teaching_Reading_Compr ehension to Students_with_Le arning Difficulties by Karen R. Harris and Steve Graham

Klingner, J. K., Vaughn, S., Boardman, A., \& Swanson, E. (2012). Now we get it! Boosting comprehension with collaborative strategic reading. San Francisco, CA, USA: Jossey-Bass.

Klingner, J. K., Vaughn, S., \& Broadman, A. (2015). Teaching reading comprehension to students with learning difficulties (2nd ed.). What works for special-needs learners (K. R. Harris and S. Graham, Eds.). New York: The Guildford Press.

Lubis, R. (2013). The Effect of applying collaborative strategic reading on grade VIII students' achievement in reading comprehension. GENRE Journal of Applied Linguistics of FBS Unimed, 2(1). Retrieved from

http://jurnal.unimed.ac.id/2012/i ndex.php/ellu/article/view/726/ $\underline{538}$

McEwan, E. K. (2004). The power of strategic reading instruction. Retrieved from https://us.corwin.com/sites/defa ult/files/upmbinaries/6863 mcewan ch 1.pd f

Mendieta, J., Múnera, L., Olmos, T., Onatra, C. Pérez, P., \& Rojas, E. (2015). Fostering reading comprehension and selfdirected learning in a collaborative strategic reading (CSR) setting. Íkala, Revista de Lenguaje y Cultura, 20(1), 1542. Retrieved from http://www.scielo.org.co/pdf/ik ala/v20n1/v20n1a2.pdf

Nourhayati, D. (2015). The effectiveness of using collaborative strategic reading (CSR) on students' reading comprehension of narrative 
text. Thesis, Department of English Education, Faculty of Tarbiyah and Teachers' Training, "Syarif Hidayatullah" State Islamic University, Jakarta, Indonesia. Retrieved from

http://repository.uinjkt.ac.id/dsp ace/bitstream/123456789/27094 11/Dede\%20Nurhayati\%20(111 0014000007)\%20(FITK).pdf

Palincsar, A. S., \& Brown, A. L. (1984). Reciprocal teaching of comprehension-fostering and comprehension-monitoring activities. Cognition and Instruction, 1, 117-175. Retrieved from http://citeseerx.ist.psu.edu/view doc/download?doi=10.1.1.648.8 749\&rep=rep1\&type $=$ pdf

Perfetti, C., \& Stafura, J. (2014). Word knowledge in a theory of reading comprehension. Scientific Studies of Reading, 18, 22-37. Retrieved from http://www.psy.cmu.edu/ siegl er/418-perfetti.pdf

Scammacca, N., Roberts, G., Vaughn, S., \& Stuebing, K. K. (2015). A meta-analysis of interventions for struggling readers in Grades 4-12: 1980-2011. Journal of Learning Disabilities, 48, 369390. Retrieved from https://www.ncbi.nlm.nih.gov/p $\underline{\text { mc/articles/PMC3975734/ }}$
Swanson, E., Mohammed, S. S., Boardman, A. G., Vaughn, S., Klingner, J., Roberts, G., et al. (2011). The effects of collaborative strategic reading instruction on the reading comprehension of middle school students: Year 2 replication. Paper presented at The SREE Spring 2011 Conference, Building an Education Science: Investigating Mechanisms, Washington, D.C. Retrieved from

https://www.sree.org/conferenc es/2011/program/downloads/abs tracts/94.pdf

Uribe-Enciso, O. (2015). Improving EFL students' performance in reading comprehension through explicit instruction in strategies. Rastros Rostros, 17(31), 37-52. Retrieved from https://dialnet.unirioja.es/servlet /articulo?codigo $=6515564$

Vaughn, S., Klingner, J. K., \& Bryant, D. P. (2001). Collaborative strategic reading as a means to enhance peer-mediated instruction for reading comprehension and content area learning. Remedial and Special Education, 22(2), 66-74. Retrieved from https://journals.sagepub.com/do $\mathrm{i} / \mathrm{pdf} / 10.1177 / 07419325010220$ $\underline{0201}$ 
Vaughn, S., Klingner, J. K., Swanson, E. A., Boardman, A. G., Roberts, G., Mohammed, S., \& Stillman-Spisak, S. J. (2011). Efficacy of collaborative strategic reading with middle school students. American Educational Research Journal, 48(4), 938-964. Retrieved from https://journals.sagepub.com/do $\mathrm{i} / \mathrm{pdf} / 10.3102 / 00028312114103$ $\underline{05}$

Wanzek, J., Wexler, J., Vaughn, S., \& Ciullo, S. (2010). Reading interventions for struggling readers in the upper elementary grades. A synthesis of 20 years of research. Reading and Writing, 23, 889-912. Retrieved from

https://www.ncbi.nlm.nih.gov/p mc/articles/PMC2975107/

Watson, S. M. R., Gable, R., Gear, S. B., \& Hughes, K. C. (2012). Evidence-based strategies for improving the reading comprehension of secondary students: Implications for students with learning disabilities. Learning Disabilities Research \& Practice, 27, 79-89. Retrieved from http://ideal-

group.org/visualizationresearch/Evidence-Based-

Strategies-for Improving-theReading-Comprehension-of-

Secondary-StudentsImplications-for-Students-withLearning-Disabilities.pdf

Zhang, L. A., \& Sheepo, S. (2013). Metacognitive strategy use and academic reading achievement: Insights from a Chinese context. Electronic Journal of English Language Teaching, 10(1), 5469. Retrieved from https://pdfs.semanticscholar. org/a0eb/6eadfb7599dcae61b 2fd9ab4301c730c2d87.pdf 